Громадське
здоров'я
Public
health

РОЗВИТОК ТЕОРІЇ ЗДОРОВ'Я - ОСНОВА ВИРІШЕННЯ ПРОБЛЕМ ОХОРОНИ ЗДОРОВ'Я

\section{Володимир ТАРАЛЛО,}

ВДНЗ України «Буковинський державний медичний університет», Чернівці (Україна)

\section{DEVELOPMENT OF THEORY OF HEALTH IS BASIS OF DECISION OF PROBLEMS OF HEALTH PROTECTION Volodymyr TARALLO, \\ Higher State Educational Establishment \\ of Ukraine «Bukovinian State Medical University», Chernivtsi (Ukraine)}

Таралло Владимир. Развитие теории здоровья - основа решения проблем здравоохранения. Представлен системный аспект понятия «здоровье». Приводятся общее (родовое) определение и дефиниция аспектных понятий: «здоровье индивида», «здоровье семьи» и «здоровье населения». Последние позволяют обозначить их индивидуальные, уникальные особенности. Конструктивность определений создала возможность выхода на измерение параметров состояний объектов. Представлены следующие интегрально-композиционные показатели: жизненный ресурс популяции, качество его использования, напряженность образа жизни, генетическая жизнестойкость популяции, потенциал и скорость адаптации ее в среде проживания, генетические риски выживания поколения. Они названы прямыми «собственными» показателями здоровья населения. Одновременно были получены измерения качества среды обитания населения, потенциала среды в стабилизации устойчивого функционирования людей в ней, страховые риски проживания в регионе.

Ключевые слова: системный анализ, интегральные показатели, здоровье населения, качество среды существования, управление здоровьем и здравоохранением.

Проблемна ситуація. Існуючі в даний час у різних країнах системи охорони здоров'я мають відношення як до здоров'я індивіда, так і до здоров'я населення в його широкому розумінні. Однак, відсутність фіксації спільних і відмінних характеристик взаємодії цих об'єктів контролю в межах діяльності відомчої системи охорони здоров'я та інших соціальних структур, пов'язаних з охороною здоров'я людей, не дозволяють вийти на прямі вимірювачі їх здоров'я, хоча всі усвідомлюють, що тільки ці характеристики і їх правильна оцінка допускають можливість створення адекватної до структури населення і релевантну його дійсному стану систему охорони, допомоги і розвитку.

Проблема. Складний і міждисциплінарний характер проблемної ситуації зумовлює необхідність пошуку такого визначення «здоров'я», дефініція якого задовольняла б різним спостережуваним умовам існування об'єкта, допускаючи і визначаючи можливість їх чіткої фіксації. Крім того, конструктив визначення повинен виводити на прямі вимірювачі цієї важливої якісної характери- стики стану об'єкта захисту. Синтез цих двох умов і $€$ найважливішою проблемою теоретичної і практичної медицини.

Історіографія проблеми. Пошукам поняття «здоров'я» були присвячені дослідження багатьох науковців-філософів, медиків, біологів, фізиків тощо, зокрема Б. Н. Ільїна, В. А. Фролова, О. М. Голяченко, Г. Сельє, I. D. Richmon, П. К. Анохіна ${ }^{1}$.

Найближче підійшли до визначення провідних системних властивостей цього поняття П. Тейяр де Шарден, Ж. Піаже, С. Б. Кримський, Т. Котарбінський, М. А. Розов, Т. Дж. Йех², але однобічність їх підходів стала перепоною виходу на родове та аспектне поняття «здоров'я», усвідомлення їх структуризації за об'єктами та їх властивостях.

Пошуку інтегральних показників здоров’я у математично-статистичному аналізі були присвячені за останні 200 років чисельні роботи, зокрема дослідження B. Compertz, W.M. Makeham, J.-F. Nys, В.П. Войтенко ${ }^{3}$,

\footnotetext{
${ }^{1}$ Il'in B. N. "O ponyatii «zdorov'ye» cheloveka” [On the concept of "health" rights], Vesnik AMN SSSR, 1988, №4, P. 15-18; Frolov V.A. Zdorov'ye [Health], BSE, Moskva, 1972, T. 9, P. 1313-1314; Holyachenko O.M. Sotsial'na medytsyna ta orhanizatsiya okhorony zdorovya [Social Medicine and Health Organization], Kyiv, PP Vihay, 1993, CH. I, P. 29-30, 49, CH. II, P. 37-43; Sel'ye G. Ocherki ob adaptatsionnom syndrome [Essays on the Adaptive Syndrome], Per. s angl. G. Sel'ye, Moskva, Medgiz, 1960, 217 p.; Richmond I.B. Currents in American medicine: A developmental view of medical care and abdication, Cambridge, Mass, 1970, P. 95; Anokhin P. K. "Teoriya funktsional'noy sistemy" [Theory of a functional system], Obshchiye voprosy fiziologicheskikh mekhanizmov, Moskva, Nauka, 1970, P. 6-43

${ }^{2}$ Teyyar de Sharden P. Fenomen cheloveka [The phenomenon of man], Per. s frants. P. Teyyar de Sharden, Moskva, Progress, 1965,288 p.; Fleyvell Dzhon K. Geneticheskaya psikhologiya Zhana Piazhe [Genetic Psychology of Jean Piaget:], Per. s angl. K.H. Fleyve ll Dzhon, Moskva, Prosveshcheniye, 1967, 623 p.; Krymskiy S.B. "O ponyatiyakh «sistema» i «struktura»" [The concepts of system and structure ], Tselosnost' i biologiya: Materialy simpoziuma, Kiyev, Naukova dumka, 1968, P. 49-60; Kotarbinskiy T. Traktat o khoroshey rabote [Treatise on Good Work], Moskva, Ekonomika, 1975, 112 p.; Rozov M. A. Problema Empiricheskogo Analiza Nauchnykh znaniy [he Problem of the Empirical Analysis of Scientific Knowledge], Novosibirsk, Nauka, 1977, 126 p.; Yyekh Tomas Dzh. Ob aksiome vybora. Spravochnaya kniga po matematicheskoy logike: Teoriya mnozhestv [About axiomedy selection], Moskva, Nauka, 1982, CH. IÍ, P. 35-63. ${ }^{3}$ Gompertz B. "On the Nature of the Function of the Law of Humen Mortality and on New Mode of Determining the Value Life Contige-
} 
Таралло В. Розвиток теорії здоров'я-основа вирімення проблем...

але, за недосконалості методологічних і методичних підходів до розв'язання чинної проблеми їх розробки мали обмежену значимість: в практику охорони здоров'я жодна 3 їх розробок не увійшла, вони навіть не висували таку мету у власних дослідженнях.

Вимоги до виконання. Системність об'єктів, що їх вивчають у медицині, людини або населення, вимагає для отримання генетичної характеристики стану їх функціонування (у т. ч. здоров'я); всі проявлені форми їх життєдіяльності слід описувати в цілісному, системному або, що те ж саме, в композиційному вигляді, тобто опис об'єкта і його функціонування має грунтуватися на врахуванні базових властивостей системи. Тільки такий підхід дозволить вийти на загальні та індивідуальні характеристики об'єкта і надасть можливість фіксації його стану, як вирішення поставленої проблеми.

Форма реалізації рішення. 3 урахуванням вимог, рішення повинно складатися 3 пошуку структурних відповідностей накопичених знань у властивостях системи 3 накопиченими медициною знаннями про людину, населення або, іншими словами, в практичному використанні прикладного системного аналізу.

Рішення проблеми полягає в реалізації технології аспектного опису та аналізу спеціальних знань про системний об'єкт за схемою: <морфологія, функціонування, організащія>, де дужки фіксують узгоджену єдність усіх базових характеристик розглядуваного об'єкта.

Схема вирішення проблеми складається 3 3-х етапів: формулювання за представленими принципами шуканого визначення «здоров'я», яке здатне «працювати» в різних середовищах існування об'єкта; вибір на тому ж грунті технології «роботи» цього визначення, що дозволяє вийти на шукані показники, i «робота» цих показників в системі практичної охорони здоров'я.

Стратегія побудови рішення завжди повинна бути орієнтована на споживача показників 3 урахуванням його місця і ролі в системі охорони здоров'я населення.

\section{Реалізація рішення.}

I. Визначення «здоров'я». В межах розробленої теоpiї про систему і структуру накопичених знань про людину і населення узагальнюючим (родовим) визначенням «здоров'я» може бути наступне:

«Здоров'я - інваріант стану організації цілеспрямовано функціонуючого об'єкта, що відображає єдність його морфологічних, функціональних та генетичних аспектів, а також здатність вирішувати виникаючі перед ним проблеми».

Це визначення при узгодженні понять повністю відповідає ВОЗівської дефініції здоров'я. Але, в той же час, воно принципово відрізняється від нього про силу своєї конструктивності.

По-перше, це поняття за своєю формальною структурою спільне для всіх системних об'єктів i, в тому числі, для всіх природних та соціально-похідних об'єктів, де триває життєдіяльність людини. Воно визначає стан об'єкта, як статусну характеристику його (роль і місце) в системному середовищі, а також якість умов взаємодії $з$ урахуванням власних внутрішніх характеристик, які забезпечують цю взаємодію (прояви: морфологічний i функціональний аспекти).

Фіксація спостерігачем напередодні або впродовж досліджень конкретних особливостей об'єкта визначає його індивідуальність та унікальність. Так, при розгляді навколишнього середовища (природного чи соціального) або способу життя окремої людини, або групи людей, як самостійних системних об'єктів, кожен 3 них має власні проявлені і спостережувані стани «здоров'я». Аналогічно i будь соціально-виробничий об'єкт, що включає людину (охорона здоров'я, лікарня чи будьякий з іiї підрозділів), при оцінці стану з позиції цілісності об'єктів, має власну спостережувану якість своєї організації, своє «здоров'я» - під ними традиційно розуміють якість реалізованих послуг. Іншими словами, поняття «здоров'я» у транскрипції «стан» - $\epsilon$ результатом неподільної, узгодженоївнутрішньої єдності морфології системного об'єкта, його функціонування (діяльності) i реалізованої еволюційної(внаслідок цієї невід'ємної єдності) спостережуваної якості організації об'єкта. Така дефініція поняття «здоров'я» виводить його в ранг видових характеристик досліджуваних об'єктів, тим самим підкреслюючи спільність формальної структури запису визначення «здоров'я» для будь-якого 3 них. Виходячи 3 цього, аспектні (часткові) визначення «здоров'я» (для індивіда, сім'ї або популяції) будуть мати наступний вигляд:

Здоров'я індивіда - інваріант стану організації цілеспрямовано функціонуючої особистості, який відображає єдність іï морфологічних, функціональних та генетичних аспектів, а також здатність вирішувати виникаючі перед нею проблеми.

Здоров'я родини - інваріант стану організації цілеспрямовано функціонуючої стійкою репродуктивної групи людей (сім'ї), що відображає єдність їі морфологічних, функціональних та генетичних аспектів, а також здатність вирішувати проблеми відтворення і виховання нащадків, збереження сім'ї та інші проблеми соціальної комунікації, що виникають перед нею.

Здоров'я населення (популящіï) - інваріант стану організації групи людей з чітко позначеним способом життя, який репрезентує єдність її структурованих морфологічного, функціонального та соціально-генетичного аспектів, а також здатність вирішувати виникаючі перед нею проблеми соціальної комунікації.

У даних визначеннях зафіксована не тільки формально-видова характеристика станів об'єкта. Внесення у визначення терміна «інваріант» відображує індивідуальність та унікальність, а також і якість спостережуваного стану кожного з наведених об'єктів. Інваріант констатує, що стан здоров'я (як інформаційний продукт) на всіх стадіях життєвого циклу об'єкта є результатом генезису (невід'ємного розвитку і зв'язку) індивідуальних морфологічних і функціональних характеристик, наслідком програмованого «вирощування» (генезис, розвиток) цього продукту з урахуванням інваріантності будови об'єкта (морфологіi) і його зв'язків (функціонування) в тому чи іншому середовищі існування.

II. Здоров'я як код управління його охороною i технології діяльності системи організації його захисту. Поглиблений розгляд складових характеристик визначення «здоров'я» дозволяє вийти на загальносоціальний спектр цілей і умов удосконалення роботи системи управління охороною здоров'я.

ncies", Philosophical Transactions of the Royal Society, London, 1825, N. 115, P. 513-585; Makeham W.M. "On the Law on Mortality”, Journal of Insitute of Actuaries, London, 1867, N. 13, P. 325-358; Nys J.-F. La Santé: Consommation Investissement [Health: Consumption Investment], Paris, 1981, 236 p.; Voytenko V.P. Faktory Smertnosti i prodolzhitel'nosti zhizni [Factors of Mortality and Lifetime], Kiev, Zdorov'ya, 1987, 148 p. 
Людина або населення в середовищі їх проживання може розглядатися як об'єкт, як якість (стан), а також як статус (з відповідним функціональним ім'ям).

Статус належить трактувати як змінну характеристику, яка окреслює певну соціальнофункціональніособливості об'єкта, що виводить на фіксацію чинного аспекту його здоров'я в системі «людина (населення) - навколишнє середовище». У сучасних наукових дослідженнях статус і його зміни фіксують на основі використання методів статистики i, зокрема, як правило, кореляційно-регресійного аналізу. За таким традиційним підходом людина (населення) в суспільстві і людина (населення), як цілісність,постають тим самим (однаковим) внаслідок того, що дослідник індуктивно узагальнює в інтегральному вимірі помічені ним статусні характеристики. Такий шлях - шлях індуктивного агрегування чинників за допомогою статистики - характерний для більшості міждисциплінарних досліджень.

Однак слід зазначити, що у наведеному підході невірно визначено об'єкт: зводячи сукупність людей до поняття «населення», аналіз результатів і одержання висновків проводиться на основі характеристик «середнього індивіда». Тобто, підставляючи термін «система», дослідники використовують методологічний підхід до «сукупності».

Визначення здоров'я як «інваріанта стану» створює зовсім інший, не пов'язаний 3 наведеним підхід у дослідженнях. Інваріант - це ядро, незмінна характеристика об'єкта як системи, де окремі властивості об'єкта подаються як різні аспекти інваріанта його стану за різними якісними характеристиками функціонування об'єкта. 3 цієї точки зору, інваріант постає як системна основа, шаблон, створений самим дослідником на основі відповідного аспекту розгляду об'єкта. 3 позиції узагальнюючого дослідження це може розглядатися як позитивна характеристика інваріанта, але, 3 іншої точки зору (обмеження зв'язків об'єкта і відповідного аналізу), це належить розглядати як обмеження позитивності інваріанта.

Використання позитивної характеристики інваріанта надає можливість, розуміючи цілісність інваріанта загалом і його частин, принципово на будь-якому щаблі ієрархічного розподілу місць «проживання» об'єкта визначати його стан, статус і відповідні властивості, наприклад, розглядати систему охорони здоров'я з позиції голови адміністрації регіону, керівника медичного закладу, дільничного лікаря або пацієнта. У кожному 3 цих випадків базові властивості об'єкта відображаються у від'ємних за ієрархією функціях і, відповідно, розподілах обов'язків і прийнятті рішень. У такому підході система управління захистом об'єкта, за визначенням інваріанта його стану (у нас - здоров'я), автоматично чіпляється за об'єкт.

Тоді, виходячи з ідеології системного аналізу, мета управління охороною здоров'я визначається як об'єднання «потоків захисту здоров'я» на всіх щаблях її ієрархії. Рішення цієї організаційно-технологічної проблеми рішення в цілому проблеми управління охороною здоров'я, яке не буде залежне від можливих змін характеру об'єкта, умов діяльності системи охорони його здоров'я або стану навколишнього середовища, що впливають на нього.

У такій системі людина і стан його здоров'я постають сигналом збудження системи управління охороною здоров'я, стають системним ядром її діяльності.
Це периий висновок з системного аналізу взаємозв'язку людини та його стану з системою охорони здоров'я.

Далі слід підкреслити наступне: виділяючи об'єкти системи охорони здоров'я (людини, населення) з базовою властивістю їх стану - здоров'ям, за зміною останнього (в аспекті поняття «інваріанта») отримують знання не тільки про них, але й про «здоров'я» системи охорони здоров'я в цілому, причому із зворотним зв'язком (кібернетичний аспект). У такому підході «система захисту» входить в поняття «здоров'я системи». Виходячи 3 цього, стає зрозумілим, що система, як цілісний об'єкт, буде захищати і стан будь-якого свого фрагмента. Тоді, визначаючи «захист» як зовнішню характеристику управління охороною здоров'я, її внутрішньою характеристикою повинен стати «контроль», який автоматично, в системному розгляді, вноситься в коло системи охорони здоров'я. завдяки цьому в разі фіксування певних рівнів ієрархії існування об'єкта в загальній системі стає можливою розробка диференційованих рекомендацій для відповідного впливу на її здоров'я» в різних підсистемах управління. Наприклад, на рівні індивіда - це рекомендації, спрямовані на власний тренаж своїх підсистем, на рівні дільничного лікаря - це призначення хворому лікувальних фармакологічних засобів, як хімічний тренаж його підсистем, для підтримки їх нормативного стану діяльності тощо. Відповідно до певних дій виникає конкретна структуризація рівнів і напрямів контролю їх виконання...

Але будь-який вплив, як відомо, неможливий без команди, як елемента керування, тобто в систему управління, у кожний окремий рівень іiі ієрархії необхідно впровадити (ввести) систему команд певними діями. 3 цією метою зовсім не обов'язково, щоб це був вплив адміністративного характеру. В системне середовище управління повинні бути введені сама людина і населення в цілому, як компоненти цього середовища, внаслідок чого належить провести перерозподіл впливів на об'єкт захисту. Безумовно, при побудові управління охороною здоров'я з урахуванням поданих пропозицій, коли захист здоров'я, як дія, що поєднується з об'єктом і порівнюється 3 його діями і станом, потоки інформації (i відповідні інструкції) повинні бути узгоджені з об'єктом, причому з урахуванням всіх базових аспектів оцінки об'єкта як системи.

Це ідеологічна основа перебудови системи охорони здоров'я і другий висновок з системного аналізу зв'язку людини (населення), їх здоров'я 3 системою охорони здоров'я. Узагальнюючим висновком тут виступає наступний: сам об'єкт (людина або населення) не байдужі до дієздатності і ефективності системи їх захисту, іiі гарантоспособности у виконанні свого призначення - захисту об'єкта, що і обгрунтовує необхідність широкого iї включення в цю систему.

III. Напрями дій управління охороною здоров'я. Розгляд базових аспектів (морфологічного, функціонального до генетичного) різних компонентів розгляду середовища існування населення показує, що провідною функціональною характеристикою змін у навколишньому середовищі людини (населення) виступає їх поведінка, як провідний віддзеркалювач способу життя.

Аналіз останнього дозволив виділити в ньому узгоджену неподільну єдність наступних елементів: $<$ традиціi, норми, ідеали>, де традиції репрезентують морфологічну характеристику змісту життєдіяльності, 
основу сформованого способу життя, виділені з них норми (нормативи) - функціональні характеристики способу життя, як напрями діяльності та обмеження, а ідеали -генетичну (наслідкову) характеристику способу життя, як мету і результат цієї діяльності. Співвідношення цих базових характеристик способу життя з базовими аспектами людини (населення) і їх станів довело, що 3 метою отримання «ідеалів здоров'я» необхідно спрямовувати дії системи управління охороною здоров'я на управління традиціями і їх нормативами. Тільки варіювання відповідними видами дій з боку системи управління дозволить 3 часом досягти сталого існування $\mathrm{i}$ забезпечити адекватну підтримку визначених суспільством ідеалів, що і доводиться в наведеній тріаді.

Це третій важливий висновок з наведеної системної оцінки взаємодії людини (населення) та середовища їх проживання, отриманий,з метою виходу на побудова дієвої системи захисту і покращання їх здоров'я.

Існуюча сьогодні система охорони здоров'я, як система, якій притаманні дискретні властивості, не може мати майбутнього. Поданийаналіз дозволяє стверджувати, що будова iï повинна бути заснована на континуальних властивостях системи: зовнішніх - гарантоздатності, модифікованості, зрозумілості і внутрішніх - стійкості, керованості та спостережуваності.

Цей методологічний підхід, заснований на виділенні об'єкта і його стану (як генетичної характеристики системної середовища), з включенням об'єкта в систему захисту його стану, відсутній у будь-якій сучасній системі охорони здоров'я населення.

IV. Загальні питання технології реалізації визначення «здоров'я» у практиці. Аспектний опис об'єкта спостереження завжди визначається стратегією побудови рішення. Якщо споживачем знань про об'єкт висту- пає керівник-організатор охорони здоров'я районного, обласного і вище щаблів, показники здоров'я населення повинні бути погоджені 3 системами використання i захисту здоров'я чинного масштабу. На рівні лікувального закладу обсяг показників та їх спектр може бути тим самим, але їх просто належить привести у відповідність 3 колом фіксованих посадових обов'язків осіб, які їх використовують в роботі (термінологія, орієнтири контролю тощо). Тільки в цьому випадку можна говорити, що $\epsilon$, відпрацьована і дотримується технологія інформаційної наступності знань про один і тойсамий об'єкт спостереження.

У загальному вигляді для будь-якої досліджуваної групи людей iï морфологія може і повинна описуватися за вибором споживача інформації. Це можуть бути, наприклад, характеристики групи за місцем проживання, за демографічним станом, за виробничим принципом тощо; існують десятки інших підходів до опису груп людей. В межах вибраної морфології виділяються відповідні до останньої закони функціонування групи на спостережуваному проміжку їі життєвого циклу і визначаються узгоджені з ними характеристики якості їі стану, у тому числі і здоров'я. Останні повинні чітко фіксувати морфологічний, функціональний та генетичний аспекти об'єкта.

V. Полем, полігоном та об'єктом досліджень нами було обрано здоров'я сільських жителів Чернівецької області. Традиційно для соціально-медичних досліджень були використані минулі і справжні події за матеріалами діючої в системі охорони здоров'я країни інформаційної бази знань про ці об'єкти: медичні та демографічні характеристики жителів 11 районів, окремі медико-соціальні характеристики останніх.

Таблиця

Геногеографічні параметри здоров'я сільського населення (обидві статі) і середовища його проживання (за матеріалами адміністративних районів Чернівецької області)

\begin{tabular}{|c|c|c|c|c|c|c|c|c|}
\hline \multirow[t]{2}{*}{$\begin{array}{l}\text { Назва } \\
\text { района }\end{array}$} & $\begin{array}{l}\text { Життєвийпот } \\
\text { енціал } \\
(\text { ресурс) - в } \\
\text { роках }\end{array}$ & $\begin{array}{l}\text { Використа } \\
\text { ний життє- } \\
\text { вийпотенціал } \\
\text { ресурс } \\
\text { (в роках) }\end{array}$ & \multirow{2}{*}{$\begin{array}{l}\text { Напруженніст } \\
\text { ьспособужитт } \\
\text { я (\%) } \\
\frac{x_{0}-e_{0}^{\circ}}{x_{0}} \times 100 \% \\
\text { w }\end{array}$} & $\begin{array}{l}\text { Генетичнажи } \\
\text { ттєстійкість } \\
\text { (індекс) }\end{array}$ & $\begin{array}{l}\text { Потен- ціал } \\
\text { адапта-ції в } \\
\text { середовищі } \\
\text { врожденажит } \\
\text { тєстійкість } \\
\text { (індекс) }\end{array}$ & $\begin{array}{l}\text { Швидкість } \\
\text { адата-ції } \\
\text { середовищі } \\
\text { (роки) }\end{array}$ & $\begin{array}{l}\text { Якість } \\
\text { в Середовища } \\
\text { прожива-- } \\
\text { ння } \\
\text { (індекс) }\end{array}$ & $\begin{array}{l}\text { Період } \\
\text { стабі- } \\
\text { лізації (роки) }\end{array}$ \\
\hline & $\mathrm{x}_{0}$ & $e_{0}^{0}$ & & $\mathrm{r}$ & $\&$ & $\mathrm{~S}$ & $\gamma$ & $\tau$ \\
\hline Вижницький & 118.86 & 71.54 & 39,8 & 3.60 & 0.92 & 4.40 & 5.32 & 18.97 \\
\hline Герцаївський & 119.02 & 72.70 & 38,9 & 1.93 & 0.74 & 11.21 & 6.31 & 16.02 \\
\hline Глибоцький & 119.04 . & 72.25 & 39,3 & 4.23 & 0.90 & 4.87 & 6.06 & 15.30 \\
\hline Заставнівський & 118.89 & 70.97 & 40,3 & 3.19 & 0.90 & 5.37 & 5.17 & 19.52 \\
\hline Кельменецький & 119.03 & 74. 90 & 37,1 & 3.11 & 0.82 & 8.38 & 7.16 & 14.12 \\
\hline Кіцманський & 118.06 & 79.82 & 32,4 & 5.98 & 0.94 & 3.22 & 8.02 & 12.47 \\
\hline Новоселицький & 119.23 & 71.58 & 39,9 & 2.94 & 0.83 & 8.03 & 6.43 & 15.74 \\
\hline Путильський & 119.07 & 70.37 & 40,9 & 1.55 & 0.72 & 12.09 & 5.60 & 18.05 \\
\hline Сокирянський & 118.01 & 79.21 & 32,9 & 9.21 & 1.13 & 0.00 & 5.17 & 19.34 \\
\hline $\begin{array}{l}\text { Сторожинець- } \\
\text { кий }\end{array}$ & 119.14 & 73.46 & 38,3 & 3.48 & 0.85 & 7.13 & 6.91 & 14.63 \\
\hline Хотинський & 119.11 & 71.45 & 40,0 & 4.07 & 0.93 & 3.76 & 5.67 & 17.84 \\
\hline Область (c/н) & 118.70 & 73.46 & 38,1 & 3.80 & 0.94 & 3.19 & 5.01 & 20.08 \\
\hline
\end{tabular}


Всі показники в регіонах (областях, районах ) визначалися з урахуванням статі, а за необхідності і міграційних процесів; вони орієнтувалися на керівника охорони здоров'я регіону. Кожен 3 них, будучи інтегральним, може бути розпакований (стратифіковані)в потрібну нам групу (спектр) параметрів стану заданих фрагментів їх власного інфрасередовища Останні також будуть репрезентувати інтегральні характеристики: їх параметри будуть відображати не лише величину, а й місце, і роль чинника у здоров'ї людей. Крім того, вони, як і базові показники, можуть далі розпаковуватися в глибину та в напрямку інших узгоджених 3 ними та їх середовищем зв'язків.

Отримані характеристики здоров'я сільських мешканців Північної Буковини показали, що всі вони є геногеографічним інваріантом. Так, невеликі коливання показника «життєвого ресурсу» довели єдність історичної спільності корінних жителів краю. Це наочно відображається в інтегральних показниках потенціалу та періоду адаптації в цьому середовищі новонароджених $(\alpha, S)$, показнику життєстійкості популяції уствореному нею самою навколишньому середовищі (r) та період іiі пристосовуваності до створених умов життя $(\tau)$, які всі разом визначають інтегральну величину показника якості цього середовища $(\gamma)$, як інваріанта антропоіндикаційної характеристики конкретного регіону. Композиція значень цих параметрів зумовила регіональні коефіцієнти напруженості способу життя (W) у кожному з районів області та можливості використання життєвого ресурсу поколіннями, що живуть в даний час.

VI. Серед наведених показників здоров'я прямими слід вважати:

- граничну тривалість життя або життєвий потенціал (ресурс) - як геногеографічну та історіографічну характеристику жителів конкретної території $\left(\mathrm{x}_{0}\right)$ - у роках;

- вроджену життєздатність та життєстійкість населення або внутрішній потенціал адаптації в середовищі, закладений попередниками (батьками) - $\alpha$ - індекс;

- зовнішню життєстійкість популяції або швидкість втрати вродженого потенціалу здоров'я і життя - як віддзеркалення антропогенного впливу («бумерангу») якості середовища існування - $\gamma$-індекс;

Похідні від них прямі показники:

- середня тривалість життя населення, як обсяг використання популяцією свого видового життєвого ресурсу $\mathrm{i}$, водночас, як інтегральна характеристика якості його використання в конкретних умовах (соціоекологічного середовища) - $\mathrm{x}_{0}^{0}$ в роках;

- генетична життєстій- кість популяції - як інтегральна характеристика іiі пристосованості до середовища існування - $\tau$-індекс.

Непрямими слід вважати:

- напруженість сформованого укладу життя популяції як відображену характеристику реалізації сукупності безлічі проявів здоров'я населення (шлюбності, народжуваності, смертності, виживання тощо) в конкретних умовах середовища проживання - $\mathrm{w}-$ в \%;

- швидкість адаптації популяції в середовищі - S - в роках;

- період стабілізації (повної соціоекологічні адаптаціï) або період дозрівання - у роках;

- страхові статево-вікові ризики збереження здоров'я і життя.

Непрямі показники здоров'я населення є прямими показниками «здоров'я» довкілля проживання (враховуючи єдність в системному середовищі населення, фізичної природи і соціальних структур).

Наведені в роботі характеристики здоров'я популяції українців (буковинців) націлені на розробку конструктивних рекомендацій щодо управління «здоров'ям»та їх мешканців регіонівз урахуванням базових варіантів прогнозу реконструкції в них суспільства. Всі вони можуть бути використані в якості інформаційної бази знань для удосконалення системи управління охороною здоров'я, покращання здоров’я людей, збільшення якості і тривалості їх життя.

Tarallo Volodymyr. Development of theory of health is basis of decision of problems of health protection.

A system aspect of the concept of the "health". Provides a General (generic) definition of "health" and the definition of aspect concepts: "the health of the individual," "family health" and "health". Latest fix not only formally species the characteristics of the States of the objects, but also allow identifying their individual, unique features. Constructive definitions give the opportunity to enter the measuring of the current status parameters of objects. Also are first obtained by the integrative and composite indices: living resource populations, as use of its vital resources, the tensions of way of life, the genetic viability of a population, vital capacity and speed of adaptation of populations in the environment, genetic risks of survival, and the like. At the same time serves to measure the quality of the living environment of the population, its potential in the stabilization or formation of stable functioning of the insurance risks of living in certain conditions. Implemented new division of indicators into "direct" and "indirect" signs in relation to health. All indicators are suitable for deeper static (decompression). The last (partial) are also integral and reflect their values the role and place of the factor in the health of the population (population). Using the new integral indicators allows to obtain a composite portrait of the processes of the health of the population on their territory, to solve the problems of improving the system of health protection, to monitor the effectiveness of relevant programs.

Key words: system analysis, integrated indicators, population health, the quality of the environment, health management and health.

Таралло Володимир - доктор медичних наук, професор кафедри сочіальної медицини та організаиії охорони здоров'я Вищого державного навчального закладу України «Буковинський державний медичний університет. Коло наукових інтересів: організація та управління охороною здоров'я.

Tarallo Volodymyr - Doctor of Medical Sciences, Professor of the Department of Social Medicine and the Organization of Health Care of Bukovinian State Medical University. Research interests: organization and management of health care.

Received: 11. 03. 2017

Advance Access Published: April, 2017

(C) V. Tarallo, 2017 